\title{
In vitro Biohydrogenation of Linolenic and Linoleic Acids by Microorganisms of Rumen Fluid
}

S. W. Lee*, Yvan Chouinard** and Binh N. Van***,

Faculty of Life Science \& Technology, Sungkyunkwan University, Korea*

Laboratory of Animal Science, Laval University, Quebec, Canada**

Central Laboratory of Thai Nguyen University of Agriculture and Forestry, Vietnam***

\author{
반추위액의 미생물에 의한 In vitro 상에서의 리놀렌산과 리놀산의 \\ Biohydrogenation \\ 이수원*, Yvan Chouinard**, Binh N. Van***, \\ 성균관대학교 생명공학부*, Laval 대학교, 캐나다**, Thai Nguyen 대학교, 베트남***
}

\begin{abstract}
리놀렌산(C18:3)과 리놀산(C18:2)의 biohydrogenation 과 반추위 내에서의 이들 지방산의 bypass를 검토하 기 위하여 3 구로 나누어 티모시 조사료를 반추위액과 함께 in vitro 상에서 $39^{\circ} \mathrm{C}, 0,3,6,9,24,36$ 시간 동안 혐기 배양 시험을 하였다. 첫번째 시험의 목적은 $\mathrm{C} 18: 2$ 과 $\mathrm{C} 18: 3$ 의 in vitro biohydrogenation에 대한 조사료의 성장 단계(stem elongation, early heading, late heading, early flowering)와 질소 시비 $(0$ and $120 \mathrm{~kg}$ $\mathrm{N} \mathrm{ha}^{-1}$ )의 영향을 시험하는 것이었다. 수소첨가가능분획(hydrogenable fraction), C18:2과 C18:3의 효과적인 소실과 bypass는 stem elongation 시 수확된 티모시에서 높았고, 성숙함에 따라 일정하게 감소하였다. 질소 시비구는 $\mathrm{C} 18: 3$ 의 수소첨가가능분획, $\mathrm{C} 18: 2$ 과 $\mathrm{C} 18: 3$ 의 효과적인 소실과 bypass가 증가하였다. 그러나 $\mathrm{C} 18: 2$ 과 $\mathrm{C} 18: 3$ 의 소실율은 성숙과 질소시비 $(\mathrm{P}>0.1)$ 에 의해 영향을 받지 않았다. 2 번째 시험에서는 in vitro $\mathrm{C} 18: 2$ 과 $\mathrm{C} 18: 3$ biohydrogenation에 대한 티모시 보존 방법의 영향을 보았다. 사일리지는 $\mathrm{C} 18: 2$ 과 $\mathrm{C} 18: 3$ 를 가장 효과적으로 소실시켰으며, 건초는 가장 효과가 낮았다. C18:2과 C18:3의 biohydrogenation 된 양은 건 초에서 보다 헤일리지와 사일리지에서 더 높았다. 티모시 헤일리지와 비교하였을 때 C18:3의 bypass는 신 선 목초, 시든풀, 건초에서 더 높았다. C18:2의 bypass는 건초와 헤일리지에 비해 신선목초와 사일리지가 더 높았다. 3 번째 시험에서는 $\mathrm{C} 18: 2$ 과 $\mathrm{C} 18: 3$ 의 소거와 bypass에 대한 티모시 헤일리지와 사일리지에 대한 개미산 첨가와 Lactobacillus plantarum 접종의 효과를 검토하였다. 개미산의 첨가는 헤일리지와 사일리지에 있어서 C18:3의 biohydrogenation 비율을 증가시켰으나 사일리지에 있어서 $\mathrm{C} 18: 2$ 의 수소첨가 가능분획을 감소시켰다. 이러한 3 가지 배양구의 결과는 티모시에 있어 $\mathrm{C} 18: 2$ 과 $\mathrm{C} 18: 3$ 의 수소첨가 가능분획과 bypass가 성숙도에 따라 감소하였고 질소시비에 따라 증가하였음을 보여 준다. 헤일리지와 사일리지에서 건초에서 보다 $\mathrm{C} 18: 2$ 과 $\mathrm{C} 18: 3$ 의 더 많은 양이 biohydrogenation 되었으며 $\mathrm{C} 18: 3$ 의 반추위 소실은 헤일리지에서 보다 신선목초, 시든풀, 건초에서 더 높았다.
\end{abstract}

(Key words : Biohydrogenation, Conjugated Linoleic Acid, Isomerization, Linoleic acid)

\section{I . INTRODUCTION}

Forage lipids are mainly galactosyglycerides and phospholipids(Weenink, 1964), and these complex lipids are rapidly hydrolysed in the rumen by bacterial extracellular lipases. Complex lipids contain large proportion of a-linolenic (C18:3) and linoleic (C18:2) acids in their constituent fatty

Corresponding author : Binh, N. Van, Central Laboratory of Thai Nguyen University of Agriculture and Forestry, Vietnam.

Tel :+84-280-852884, Fax :+84-280-852921, E-mail :ngbinh2002@yahoo.com 
acids (Weenink, 1961). These two polyunsaturated fatty acids (PUFA) liberated by lipolysis are adsorbed onto feed particles where they are hydrogenated by rumen microorganisms (Demeyer and Doreau, 1999). The initial step in the biohydrogenation of a-linolenic (cis-9, cis-12, cis-15 C18:3), and linoleic acid (cis-9, cis-12 $\mathrm{C} 18: 2)$ is the conjugation of the double bond cis-9, cis-12 by the action of cis-12, trans-1 isomerase (Kepler et al., 1970). This isomerization yields to the formation of cis-9, trans-1 C18 conjugated acids, and is followed by the hydrogenation of cis-9 double bond. The products from C18:3, trans-11, cis-15 C18:2 are further hydrogenated to trans-1 C18:1 (vaccenic acid), and finally to $\mathrm{C} 18: 0$ by mixed rumen bacteria (Kemp and Lander, 1983). Studies with pure strains of rumen bacteria had show that most bacteria are capable to hydrogenate C18:2 to trans-C18:1 and related isomers, but only a few bacteria had the ability to hydrogenate $\mathrm{C} 18: 2$ not only to trans-C18:1, but also to stearic acid (C18:0) (Fujimoto et al., 1993).

Biohydrogenation of PUFA in the rumen is affected by many factors such as the type and amount of fatty acid substrate (Noble et al. 1974), N content of the diet (Gerson et al., 1983), forage to concentrate ratio in the diet (Gerson et al., 1985), age of the mixed culture, type of the inoculum (Kellens et al., 1986), and the $\mathrm{pH}$ of rumen fluid (Van Nevel and Demeyer, 1996). The concentration of C18:2 present in the incubation mixture is a major factor affecting the pattern of hydrogenation (Harfoot et al., 1973).

Conjugated linoleic acid, cis-9, trans-11 C18:2 (CLA), is also an intermediate product of biohydrogenation of $\mathrm{C} 18: 2$ by the rumen bacterium Butyrivibrio fibriosolvens (Kepler and Tove, 1967). Fujimoto et al. (1993) reported that a Selenomonas ruminantium and Butyrivibrio fibriosolvens could isomerize C18:2 to trans- 9 C18:1 (eladic acid). Normally, the trans-11 C18:1 is the major isomer found in rumen (Harfoot, 1981; Kemp and Lander, 1984) since it represents at least $80 \%$ of the total rumen trans C18:1 (Demeyer and Doreau, 1999). It appears to be the penultimate end-product in the biohydrogenation of $\mathrm{C} 18: 2$ and $\mathrm{C} 18: 3$ that is slowly hydrogenated to C18:0 compared with cis-9 C18:1 (oleic acid) (Kemp and Lander, 1984).

Recently, attention had been given to omega-3 PUFA, such as C18:3 which are recognized as healthy fatty acids for human by their beneficial cardiovascular and anti-inflammatory properties (Williams, 2000). CLA possess anticarcinogenic properties as well as anti-lipogenic and immuosuppressive effects (Williams, 2000). Ruminant meat and dairy products are significant sources of CLA (Dhiman et al., 1999). However, they contain approximately only $1 \%$ of $\mathrm{C} 18: 3$ despite the high content of $\mathrm{C} 18: 3$ in lipids of pasture grazed by ruminants and in oilseeds such as canola in their diets (Ashes et al., 1997). The low content of $\mathrm{C} 18: 3$ in milk is due to an extensive biohydrogenation of PUFA in the rumen with consequently the formation of transC18:1 and C18:0 (Gulati et al., 1997).

The FA composition of total lipids of various forage plants is dominated by high proportions of unsaturated a-linolenic (C18:3) and linoleic (C18:2) acids (Harfoot and Hazlewood, 1988), but small amounts of oleic acid (C18:1) are also present (Harfoot, 1981). In fresh grasses, C18:3 represent between 50 and $75 \%$ of total FA (TFA) (Hawke, 1973), C18:2 and palmitic acid (C16:0) acids are the next most abundant (McDonald et al., 1988). Lough and Aderson have also found that $\mathrm{C} 18: 3$ was the major component of the esterified FA (simple and complex lipids) of mixed pasture grasses including ryegrass, timothy and meadow fescue. However, in ensiled grasses, C18:3 was present in small proportion in the esterified FA and absent from complex lipids of silage. The FA concentration in forages varied 
with many factors such as species and senescence (Harfoot and Hazlewood, 1988; Harwood, 1980), growth stage (Bauchart et al., 1984), conservation methods (Lough and Anderson, 1973; Yang and Fujita, 1997), as well as wilting, shading and silage additives (Dewhurst and King, 1998).

The addition of formic acid to fresh or wilted ryegrass leads to a decrease in silage fermentation and consequently a small production of acetic, lactic and butyric acids (Dewhurst and King, 1998). However, we ignore the effect of silage additives on their isomerization and biohydrogenation of forage unsaturated fatty acids in the rumen and the amount of these fatty acids that could pass out the rumen. One way to increase milk fat content of $\mathrm{C} 18: 3$ could be to increase the rumen outflow of this fatty acid. The objectives of the present research was to study the influence of the growth stage, $\mathrm{N}$-fertilization, conservation methods, and silage additives, such as formic acid and lactic acid bacteria (LAB), on in vitro biohydrogenation of C18:2 and C18:3 fatty acids and to evaluate their ruminal bypass.

\section{MATERIALS AND METHODS}

\section{Experiment trials}

\section{(1) Trial 1}

Sixty four plots $\left(3.25 \mathrm{~m}^{2}\right)$ of timothy, cultivar Champ, were used in a $2 \times 4$ factorial design; two levels of $\mathrm{N}$-fertilization ( 0 and $120 \mathrm{~kg} \mathrm{ha}^{-1}$ ) and four growth stages (stem elongation, SE; early heading, EH; Late heading, LH; and early flowering, EF). The harvest interval is one week between each growth stage. A forage sample with the parts can be used as feed for cows (c.a $250 \mathrm{~g}$ ) was taken from each plot at each harvest, dried at $55{ }^{\circ} \mathrm{C}$ in a forced-draft oven for $3 \mathrm{~d}$, and ground using a Wiley mill (Standard Model 3, Arthur H. Thomas Co., Philadelphia, PA) fitted with a $1-\mathrm{mm}$ screen.

\section{(2) Trial 2}

In this trial, different conservation treatments of timothy harvested at early heading stage were studied. A part of a timothy field was harvested at $5-\mathrm{cm}$ height with a hand clipper. The fresh grass (FG) material (230 $\mathrm{g} \mathrm{DM} \mathrm{kg}^{-1}$ ) was separated into two parts. One part was spread out uniformly on wire netting and was either fieldwilted for few $\mathrm{h}$ to reach $400 \mathrm{~g} \mathrm{DM} \mathrm{kg}^{-1}$ (wilted grass, WG), or for $3 \mathrm{~d}$ until $850 \mathrm{~g} \mathrm{DM} \mathrm{kg}^{-1}$ (grass hay, GH). The WG and the second part of the fresh material were used to make mini silos. After $60 \mathrm{~d}$ of fermentation, silos were opened and emptied. Samples of FG, WG, GH, haylage (400 $\left.\mathrm{g} \mathrm{DM} \mathrm{kg}^{-1}, \mathbf{H}\right)$, and silage $\left(230 \mathrm{~g} \mathrm{~kg}^{-} 1, \mathbf{S}\right)$ were frozen and lyophilized. All lyophilized samples were ground at $1 \mathrm{~mm}$ (Standard Model 3, Arthur H. Thomas Co., Philadelphia, PA).

\section{(3) Trial 3}

Timothy haylage and silage were made as described in the previous section but LAB (Lactobacillus plantarum) inoculant or formic acid was added to the forage before making silage. There were a total of 6 treatments (Table $1)$.

Table 1. Treatments applied to timothy haylage and silage (Trial 3)

\begin{tabular}{lccc}
\hline Treatment & $\begin{array}{c}\text { Dry matter } \\
\left(\mathrm{g} \mathrm{kg}^{-1}\right)\end{array}$ & Additive & Level \\
\hline \hline Haylage, H & 40 & - & - \\
Haylage, Hi & 40 & LAB & $10^{6} \mathrm{CFUg}^{-1} \mathrm{FM}$ \\
Haylage, Hfa & 40 & Formic acid & $6 \mathrm{~L} \mathrm{t}^{-1} \mathrm{FM}$ \\
& & & - \\
Silage, S & 23 & - & - \\
Silage, Si & 23 & LAB & $10^{6} \mathrm{CFUg}^{-1} \mathrm{FM}$ \\
Silage, Sfa & 23 & Formic acid $6 \mathrm{~L} \mathrm{t}^{-1} \mathrm{FM}$ \\
\hline
\end{tabular}

LAB : Lactobacillus plantarum inoculant.

CFU : Colony forming units.

FM : Fresh matter. 


\section{Rumen fluid collection}

A rumen fistulated Holstein cow in early lactation was used as a donor of rumen content. This cow was fed trefoil-fescue and orchard grass-timothy silages (12 meals day $\left.{ }^{-1}\right)$, timothy hay (3 $\mathrm{kg}$ fresh matter $(\mathrm{FM}) \mathrm{day}^{-1}$ ), commercial concentrate (Purina 1233 Lactena B16), and mineral (150 $\left.\mathrm{g} \mathrm{FM} \mathrm{day}^{-1}\right)$ and vitamin (300 g FM day ${ }^{-1}$ ) supplements. The nutrient composition of dietary ingredients is presented in Table 2 . Two $\mathrm{L}$ of rumen fluid was collected and was immediately poured into a $39{ }^{\circ} \mathrm{C}$ pre-warmed thermos. Two handles of fibrous material from the rumen content were added in the thermos, which was the completely filled with rumen fluid in order to assure anaerobic conditions during transportation. The thermos content was emptied in a $39{ }^{\circ} \mathrm{C}$ pre-warmed and $\mathrm{CO}_{2}$ gassed blender (Warning Commercial Blender) and mixed at a high speed during $30 \mathrm{~s}$ in order to dislodge microorganismss associated to solid particles of the rumen content. The mixed rumen fluid was strained through four layers of cheesecloth and the inoculum was mixed with a magnetic stirrer and maintained at $39{ }^{\circ} \mathrm{C}$ under anaerobic conditions.

Table 2. Nutrient composition of dietary ingredients

\begin{tabular}{lrrrr}
\hline Nutrient & $\begin{array}{c}\text { Trefoil- } \\
\text { fescue } \\
\text { Silage }\end{array}$ & $\begin{array}{c}\text { Orchard } \\
\text { grass- } \\
\text { timothy } \\
\text { silage }\end{array}$ & $\begin{array}{c}\text { Timothy } \\
\text { hay }\end{array}$ & Concentrate \\
\hline \hline $\mathrm{DM}$ & 94.8 & 94.4 & 95.5 & 95.2 \\
$\mathrm{CP}$ & 12.9 & 11.8 & 11.6 & 20.1 \\
$\mathrm{ADF}$ & 30.7 & 32.1 & 34.2 & 6.4 \\
$\mathrm{NDF}$ & 51.9 & 50.7 & 58.4 & 15.5 \\
$\mathrm{P}$ & 0.2 & 0.2 & 0.3 & 0.7 \\
$\mathrm{EE}$ & 3.1 & 2.7 & 2.7 & 8.4 \\
\hline
\end{tabular}

$\mathrm{DM}, \mathrm{CP}, \mathrm{ADF}, \mathrm{NDF}, \mathrm{P}$ and $\mathrm{EE}=$ dry matter, crude protein, acid detergent fiber, neutral detergent fiber, phosphorus and ether extract.

\section{In vitro biohydrogenation method}

Three different incubations were done separately, one for each trial. Timothy samples $(250 \mathrm{mg})$ were incubated in duplicate in $50 \mathrm{~mL}$ glass tube with $25 \mathrm{~mL}$ of McDougall buffer $(\mathrm{pH}$ 6.9) and 5 $\mathrm{mL}$ of rumen inoculum. A standard timothy sample was used as control in all incubation. Blank tubes containing only the inoculum and McDougall buffer were also included in all incubations. All tubes were gassed with $\mathrm{CO}_{2}$, tightly fitted with rubber stopper equipped with a gas release valve, and incubated at $39{ }^{\circ} \mathrm{C}$ for $0,3,6,9,24$, or $36 \mathrm{~h}$. The rotating platform of the incubator (Lab-line, Environ-Melrose Park, IL) was adjusted at 175 turns $\min ^{-1}$. At the end of each incubation period, tubes were withdrawn and immediately frozen. Frozen tubes were lyophilized during five to seven days for further fatty acid analysis.

\section{Fatty acid analysis}

Fatty acids in lyophilized incubation mixture were extracted and methylated following a one-step procedure (Sukhija and Palmquist, 1988) using toluene as solvent. Methyl nonadecanoate was used as an internal standard. Fatty acid methyl esters were quantified by gas chromatography using a HP 5890 chromatograph (Hewlett Packard Co.) under the following condition: $600 \mathrm{~m} \times 0.32 \mathrm{~mm}$ DB-23 capillary column, $0.25 \mu \mathrm{m}$ film thickness, $\mathrm{H}_{2}$ carrier gas, $2.8 \mathrm{~cm}^{3} \mathrm{~min}^{-1}$ volumetric flow rate, injector split $1 / 100$ at $240{ }^{\circ} \mathrm{C}$, septum purge vent at $2 \mathrm{ml} \min ^{-1}$, flame ionization detector at $250^{\circ} \mathrm{C}$, and $15 \mathrm{kPa}$ of heat pressure. The initial temperature was $150{ }^{\circ} \mathrm{C}$, which was increased $5{ }^{\circ} \mathrm{C} \min ^{-1}$ up to $200{ }^{\circ} \mathrm{C}$. Fatty acid methyl esters in toluene were directly injected through the split injection port. Peak area of each fatty acid was measured using a Turbochrom 3 analytical system (Version 3.3; PE Nelson). Each peak was identified and quantified using pure methyl ester standards (Alletch, Deer- 
field, IL).

\section{Statistical analyses}

PUFA are not extensively metabolized by ruminal microorganisms. The amount of $\mathrm{C} 18: 2$ and $\mathrm{C} 18: 3$ disappearing from the incubation mixture were therefore considered to be biohydrogenated. The disappearance of $\mathrm{C} 18: 2$ and $\mathrm{C} 18: 3$ in timothy samples during the in vitro incubation was described according to the following equation:

$$
\mathrm{Pt}=\mathrm{x}+\mathrm{y}^{*} \mathrm{e}^{-\mathrm{zt}}
$$

where

$\mathrm{Pt}=$ amount $\left(\mathrm{mg} \mathrm{g}^{-1} \mathrm{DM}\right)$ of timothy $\mathrm{C} 18: 2$ and

C18:3 present in the incubation mixture at time $\mathrm{t}(\mathrm{h})$,

$\mathrm{x}=$ non-hydrogenable fraction of C18:2 and C18:3 in timothy ( $\left.\mathrm{mg} \mathrm{g}^{-1} \mathrm{DM}\right)$,

$\mathrm{y}=$ hydrogenable fraction of $\mathrm{C} 18: 2$ and $\mathrm{C} 18: 3$,

$\mathrm{z}=$ rate of disappearance of fraction $\mathrm{y}\left(\% \mathrm{~h}^{-1}\right)$

$\mathrm{t}$ = incubation time ( $\mathrm{h}$ )

Effective disappearance (ED) of C18:2 and 18:3 were calculated using a rate of passage $(\mathrm{k})$ of $0.06 \mathrm{~h}^{-1}$ as followed:

$$
\mathrm{ED}=\mathrm{y}(\mathrm{z} /(\mathrm{z}+\mathrm{k}))
$$

The bypass (BP) of C18:2 and C18:3, defined as the amount of $\mathrm{C} 18: 2$ and $\mathrm{C} 18: 3$ that potentially escape from the rumen biohydrogenation, was estimated using this equation:

$$
\mathrm{BP}=\mathrm{x}+\mathrm{y}-\mathrm{ED} .
$$

The appearance of C18:0 in timothy during the biohydrogenation process was estimated by the model of Orskov and MacDonald (1979):

$$
\mathrm{Pt}=\mathrm{a}+\mathrm{b}\left(1-\mathrm{e}^{-\mathrm{ct}}\right) \text {. }
$$

where

$\mathrm{Pt}=$ amount (mg $\left.\mathrm{g}^{-1} \mathrm{DM}\right)$ of timothy $\mathrm{C} 18: 0$

present in the incubation mixture at time $\mathrm{t}(\mathrm{h})$,

$\mathrm{a}=$ amount of $\mathrm{C} 18: 0\left(\mathrm{mg} \mathrm{g}^{-1} \mathrm{DM}\right)$ present in the incubation mixture at time 0 ,

$\mathrm{b}=$ amount of C18:0 (mg $\mathrm{g}^{-1} \mathrm{DM}$ ) appearing during the biohydrogenation process,

$\mathrm{c}=$ rate of appearance of fraction $\mathrm{b}\left(\% \mathrm{~h}^{-1}\right)$, $\mathrm{t}=$ incubation time $(\mathrm{h})$

Effective appearance (EA) was estimated, with a rate of passage (k) of $0.06 \mathrm{~h}^{-1}$ as followed:

$$
\mathrm{BP}=\mathrm{a}+\mathrm{EA} \text {. }
$$

The parameters $\mathrm{x}, \mathrm{y}, \mathrm{z}, \mathrm{a}, \mathrm{b}, \mathrm{c}, \mathrm{ED}, \mathrm{EA}$, and BP for each fatty acid and each treatment were calculated according to the nonlinear Marquardt procedure of SAS (SAS Institute, Inc. 1985). In trial 1, data for parameters $\mathrm{x}, \mathrm{y}, \mathrm{z}, \mathrm{a}, \mathrm{b}, \mathrm{c}, \mathrm{ED}$, $\mathrm{EA}$, and BP were subjected to ANOVA by the GLM procedure of SAS (SAS Institute, Inc. 1985) according to a split plot factorial design. Growth stages were the main plot, and Nfertilization was the subplot with four replications per treatment. Quantitative contrasts were used to test linear, quadratic, and cubic effects of growth stage and the interactions between growth stage and $\mathrm{N}$-fertilization. In trial 2 and 3, data were analyzed using the GLM procedure of SAS (SAS Institute, Inc. 1985) as a randomized design with four replications per treatment. In trial 2, the parameters for each fatty acid were compared using the LSD test (SAS Institute, Inc. 1985). In trial 3, simple contrasts were used to test differences between treatments.

\section{RESULTS AND DISCUSSION}

\section{Effect of growth stage}

The curves of kinetic disappearance of $\mathrm{C} 18: 2$ and $\mathrm{C} 18: 3$, an appearance of $\mathrm{C} 18: 0$ during the in vitro incubation of timothy harvested at different growth stages is presented in Figure 1. The disappearance of the hydrogenable fraction (y) of C18:2 and C18:3 were almost completed after 9 $\mathrm{h}$ of incubation. However, a portion of the initial concentration of $\mathrm{C} 18: 2$ and $\mathrm{C} 18: 3$ remained in the incubation mixture after $36 \mathrm{~h}$ (fraction $\mathrm{x}$ ).

The hydrogenable fraction of $\mathrm{C} 18: 2$ and $\mathrm{C} 18: 3$ as well as the amount of C18:0 appearing during the biohydrogenation process decreased linearly 
with maturity (Table 3 and Figure 1). In contrast, the non-hydrogenable fractions of $\mathrm{C} 18: 2$ and $\mathrm{C} 18: 3$ were not significantly affected by growth stage $(\mathrm{P}>0.1)$. The $\mathrm{ED}$ of $\mathrm{C} 18: 3$ and $\mathrm{C} 18: 2$, and the EA of $\mathrm{C} 18: 0$ were high in timothy harvested at SE, and decreased linearly with maturity

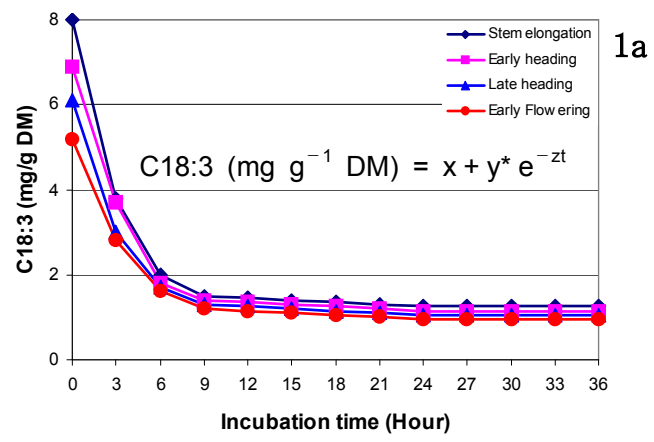

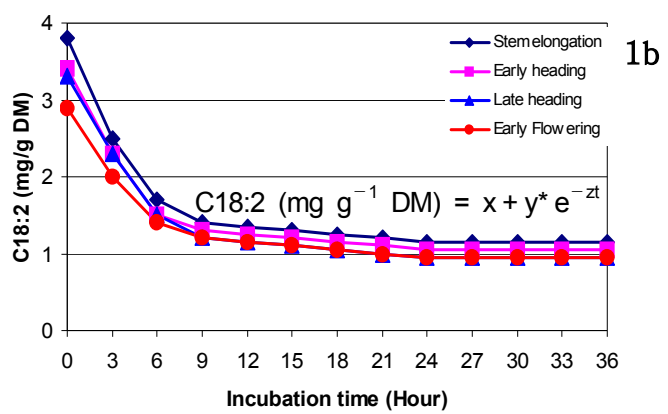

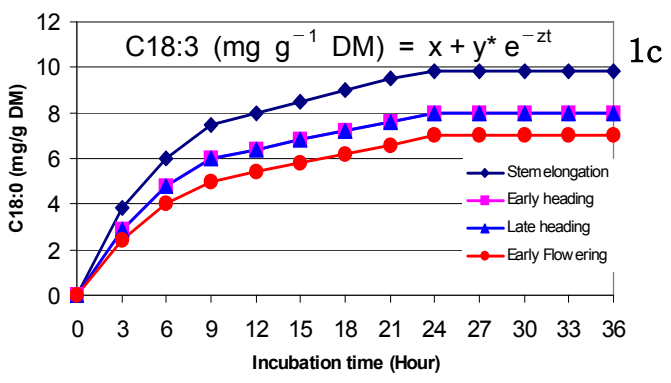

Fig. 1. Curves of kinetic disappearance of $C 18: 3(1 a)$ and $C 18: 2(1 b)$ and appearance of C18:0(1c) during the in vitro incubation of timothy harvested at different growth stages, $x$ $=$ non hydrogenable fraction of $\mathrm{C} 18: 2$ and $\mathrm{C} 18: 3$ in timothy ( $\left.\mathrm{mg} \mathrm{g}^{-1} \mathrm{DM}\right), \mathrm{y}=$ hydrogenable of $\mathrm{C} 18: 2$ and $\mathrm{C} 18: 3$ in timothy $\left(\mathrm{mg} \mathrm{g}^{-1} \mathrm{DM}\right), \mathrm{z}=$ rate of disappearance of fraction y $\left(\% \mathrm{~h}^{-1}\right), \mathrm{a}=$ amount of $\mathrm{C} 18: 0\left(\mathrm{mg} \mathrm{g}^{-1} \mathrm{DM}\right)$ in th incubation mixture at time $0, \mathrm{~b}=$ amount of $\mathrm{C} 18: 0\left(\mathrm{mg} \mathrm{g}^{-1} \mathrm{DM}\right)$ appearing during the biohydrogenation process, $\mathrm{C} 18: 2$ and $\mathrm{C} 18: 3=$ rate of appearance of fraction $\mathrm{b}\left(\% \mathrm{~h}^{-1}\right)$ and $\mathrm{t}=$ incubation time $(\mathrm{h})$.

Table 3. Biohydrogenation of $\mathrm{C} 18: 2$ and $\mathrm{C} 18: 3$ and appearance of $\mathrm{C} 18: 0$ during in vitro incubation of timothy at four growth stages and two levels of $\mathrm{N}$-fertilization (Trial 1)

\begin{tabular}{|c|c|c|c|c|c|c|c|c|c|c|c|c|c|c|c|c|}
\hline \multirow{3}{*}{\multicolumn{2}{|c|}{$\begin{array}{l}\text { Fatty acid } \\
\text { parameter }\end{array}$}} & \multicolumn{8}{|c|}{ Treatment } & \multirow{2}{*}{\multicolumn{7}{|c|}{$\begin{array}{c}\text { Probability }^{2)} \text { of treatment and contrast } \\
\text { effects }\end{array}$}} \\
\hline & & \multicolumn{4}{|c|}{$0 \mathrm{~kg} \mathrm{~N} \mathrm{ha}^{-1}$} & \multicolumn{4}{|c|}{$120 \mathrm{~kg} \mathrm{~N} \mathrm{ha}^{-1}$} & & & & & & & \\
\hline & & SE & $\mathrm{EH}$ & LH & $\mathrm{EF}$ & SE & $\mathrm{EH}$ & LH & $\mathrm{EF}$ & $\mathrm{GS}_{\mathrm{L}}$ & $\mathrm{GS}_{\mathrm{Q}}$ & $\mathrm{GS}_{\mathrm{C}}$ & $\mathrm{N}$ & $\mathrm{GS}_{\mathrm{LXN}}$ & $\mathrm{GS}_{\mathrm{QXN}}$ & $\mathrm{GS}_{\mathrm{CXN}}$ \\
\hline \multirow[t]{5}{*}{$\mathrm{C} 18: 2$} & $\mathrm{x}$ & 0.93 & 0.80 & 0.64 & 0.72 & 0.90 & 0.85 & 1.00 & 0.99 & NS & NS & NS & *** & $* *$ & NS & NS \\
\hline & $\mathrm{y}$ & 2.74 & 2.25 & 2.25 & 2.01 & 3.00 & 2.75 & 2.50 & 1.98 & $* *$ & NS & NS & NS & NS & NS & NS \\
\hline & $\mathrm{Z}$ & 0.23 & 0.20 & 0.18 & 0.20 & 0.20 & 0.20 & 0.20 & 0.20 & NS & NS & NS & NS & NS & NS & NS \\
\hline & ED & 2.16 & 1.73 & 1.62 & 1.55 & 2.31 & 2.12 & 1.92 & 1.52 & $* *$ & NS & NS & \# & NS & NS & NS \\
\hline & BP & 1.51 & 1.32 & 1.27 & 1.18 & 1.59 & 1.48 & 1.58 & 1.45 & $* *$ & NS & NS & $* *$ & \# & NS & NS \\
\hline \multirow[t]{5}{*}{$\mathrm{C} 18: 3$} & $x$ & 0.91 & 0.73 & 0.69 & 0.76 & 1.06 & 1.16 & 0.95 & 0.92 & NS & NS & NS & $* *$ & NS & * & NS \\
\hline & $\mathrm{y}$ & 6.25 & 4.99 & 4.25 & 3.75 & 7.76 & 7.02 & 6.25 & 5.00 & $* *$ & NS & NS & $* *$ & NS & NS & NS \\
\hline & Z & 0.33 & 0.28 & 0.30 & 0.33 & 0.32 & 0.30 & 0.30 & 0.30 & NS & NS & NS & NS & NS & NS & NS \\
\hline & ED & 5.28 & 4.09 & 3.54 & 3.17 & 6.53 & 5.85 & 5.21 & 4.17 & $* *$ & NS & NS & $* *$ & $\mathrm{~N}$ & NS & NS \\
\hline & $\mathrm{BP}$ & 1.88 & 1.64 & 1.40 & 1.35 & 2.28 & 2.33 & 1.99 & 1.76 & $* *$ & NS & NS & $* *$ & NS & \# & NS \\
\hline \multirow[t]{5}{*}{$\mathrm{C} 18: 0$} & $\mathrm{a}$ & 0.04 & 0.31 & -0.15 & 0.06 & 0.49 & -0.48 & -0.15 & -0.26 & NS & NS & NS & NS & $\overline{N S}$ & NS & \# \\
\hline & b & 9.04 & 7.46 & 7.19 & 7.21 & 10.40 & 10.14 & 8.97 & 8.34 & $* *$ & NS & NS & $* *$ & & & NS \\
\hline & $\mathrm{c}$ & 0.16 & 0.13 & 0.13 & 0.12 & 0.13 & 0.14 & 0.15 & 0.13 & NS & NS & NS & NS & $\mathrm{N}$ & NS & NS \\
\hline & EA & 6.58 & 5.46 & 4.74 & 4.85 & 7.52 & 6.58 & 6.14 & 5.40 & $* *$ & NS & NS & ** & NS & NS & NS \\
\hline & BP & 6.62 & 5.77 & 4.59 & 4.91 & 8.01 & 6.10 & 5.99 & 5.15 & $* *$ & \# & NS & * & NS & NS & \\
\hline
\end{tabular}

1) The hydrogenation of $\mathrm{C} 18: 2$ and $\mathrm{C} 18: 3$ was described according to the equation $\mathrm{Pt}=\mathrm{x}+\mathrm{y} \mathrm{e^{-zt }}$, The appearance of $\mathrm{C} 18: 0$ was described according to the equation $\mathrm{Pt}=\mathrm{a}+\mathrm{b}\left(1-\mathrm{e}^{-\mathrm{ct}}\right)$,

2) NS, \#, *,**, non significant, and significant at $\mathrm{P}<0.1, \mathrm{P}<0.05$, and $\mathrm{P}<0.01$, respectively.

3) $\mathrm{L}, \mathrm{Q}, \mathrm{C}=$ Linear, quadratic, and cubic effect of growth stage (GS), respectively.

$\mathrm{SE}, \mathrm{EH}, \mathrm{LH}$ and $\mathrm{EF}=$ Stem elongation, early heading, late heading and early flowering. 
(Table 3). We previously observed that concentrations of $\mathrm{C} 18: 2$ and $\mathrm{C} 18: 3$ in timothy decreased linearly with maturity. This result explains the linear decrease of the hydrogenable fraction of C18:2 and C18:3 in timothy observed with advance in maturity.

The rate of disappearance of $\mathrm{C} 18: 2$ and $\mathrm{C} 18: 3$ and the rate of appearance of $\mathrm{C} 18: 0$ were not affected by maturity $(\mathrm{P}>0.1)$. The bypass of $\mathrm{C} 18: 2, \mathrm{C} 18: 3$, and $\mathrm{C} 18: 0$ were higher at SE and decreased linearly with maturity. The amount of C18:2 and C18:3 potentially escaping the ruminal biohydrogenation (BP) were 14 and $25 \%$ higher in timothy harvested at SE as compared with EF. The amount of C18:0 potentially leaving the rumen was $31 \%$ higher at $\mathrm{SE}$ than at $\mathrm{EF}$.

No trans-C18:1 was detected in timothy grass harvested at different growth stages. However, the concentration of trans-C18:1 in the incubation mixture increased gradually during the first $9 \mathrm{~h}$ of incubation, then remained at a constant level until the end of incubating period (Figure 2, 2a). This kinetic of trans-C18:1 concentration in the incubation mixture did not fit in the models used for $\mathrm{C} 18: 2, \mathrm{C} 18: 3$, and $\mathrm{C} 18: 0$. The average concentrations of trans-C18:1 between 9 and 36 $\mathrm{h}$ of incubation were therefore used for statistical analysis (Table 4).

Trans-C18:1 are among intermediate produced during ruminal biohydrogenation of $\mathrm{C} 18: 2$ and C18:3. Many isomers have been identified, including trans-9 C18:1 (Fujimoto et al., 1993), as well as trans-15 and trans-11 C18:1 (Harfoot and Hazlewood, 1988). Among those intermediates, trans-11 C18:1 is the most abundant trans isomer of $\mathrm{C} 18: 1$ produced in the rumen under the normal feeding conditions (Harfoot and Hazlewood, 1988). However, the method used to determine

Table 4. Concentrations of cis-C18:1 and trans $-18: 1$ in timothy at growth stages and two levels of $\mathrm{N}$ - fertilization after different incubation periods (Trial 1)

\begin{tabular}{|c|c|c|c|}
\hline & \multicolumn{3}{|c|}{ Fatty acid (mg g $\left.{ }^{-1} \mathrm{DM}\right)$} \\
\hline & trans-C18:1 & $c i s_{i}-18: 1$ & $\operatorname{cis}_{f}-18: 1$ \\
\hline \multicolumn{4}{|l|}{ Growth stage } \\
\hline Stem elongation & 1.97 & 0.45 & 0.04 \\
\hline Early heading & 1.50 & 0.45 & -0.10 \\
\hline Late heading & 1.50 & 0.33 & 0.01 \\
\hline Early flowering & 1.41 & 0.22 & -0.04 \\
\hline SEM & 0.11 & 0.07 & 0.17 \\
\hline \multicolumn{4}{|l|}{$\mathrm{N}-$ fertilization $\left(\mathrm{kg} \mathrm{ha}^{-1}\right)$} \\
\hline 0 & 1.32 & 0.25 & -0.17 \\
\hline 120 & 1.87 & 0.47 & 0.12 \\
\hline SEM & 0.15 & 0.10 & 0.23 \\
\hline Source of variation & & Probability $^{\mathrm{a}}$ & \\
\hline Growth stage (GS) & $* *$ & $*$ & NS \\
\hline Linear effect $\left(\mathrm{GL}_{\mathrm{L}}\right)$ & $*$ & $* *$ & NS \\
\hline Quadratic effect $\left(\mathrm{GS}_{\mathrm{Q}}\right)$ & NS & NS & NS \\
\hline Cubic effect $\left(\mathrm{GS}_{\mathrm{C}}\right)$ & NS & NS & NS \\
\hline $\mathrm{N}$-fertilization $(\mathrm{N})$ & $* *$ & $* *$ & $*$ \\
\hline Growth stage $\times \mathrm{N}$-fertilization & NS & NS & NS \\
\hline $\mathrm{GS}_{\mathrm{L}} \times \mathrm{N}$ & NS & NS & NS \\
\hline $\mathrm{GS}_{\mathrm{Q}} \times \mathrm{N}$ & $\#$ & $\#$ & NS \\
\hline $\mathrm{GS}_{\mathrm{C}} \times \mathrm{N}$ & NS & NS & NS \\
\hline
\end{tabular}

a) $\mathrm{NS}, \#, *, * *=$ non significant, and significant at $\mathrm{P}<0.1, \mathrm{P}<0.05$, and $\mathrm{P}<0.01$, respectively. 
the FA profile did not allow for a complete separation of different trans isomers of $\mathrm{C} 18: 1$. The sum of trans $-\mathrm{C} 18: 1$ is therefore reported (Figure 2, 2a and Table 4). The average concentration of trans-C18:1 after 9, 24, and $36 \mathrm{~h}$ of incubation was higher in SE samples, and it decreased linearly with maturity of timothy (Table 4). The linear decrease of trans-C18:1 concentration observed with the advance in maturity of timothy was probably related to the decreased hydrogenable fraction of either C18:2 and C18:3 (Table 3).
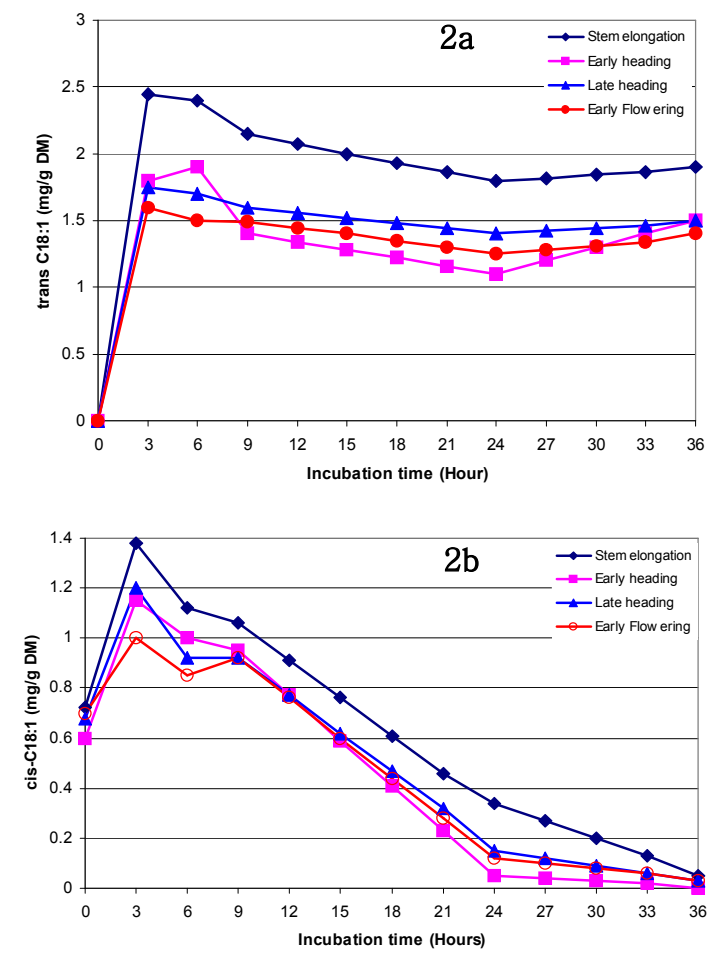

Fig. 2. Concentration of trans-C18:1 (2a) and cis-C18:1 (2b) during the in vitro incubation of timothy harvested at different growth stages.

The concentration of cis-C18:1 in timothy grass was not affected by growth stages. The concentration of cis-C18:1 increased rapidly during the first $3 \mathrm{~h}$ of incubation (Figure 2, 1b) for all treatments. According to the metabolic biohydrogenation pathway of C18:3 described by Harfoot (1981), cis-9, cis-12, cis-15 C18:3 are metabolized to cis-12, cis-15 C18:2 isomer. The cis-12 double bond of this $\mathrm{C} 18: 2$ isomer is then reduced to form cis-15 C18:1 which is further hydrogenated to C18:0. The formation of cis-15 C18:1 as an intermediate during the biohydrogenation of C18:3 may explain the temporary increase in the concentration of cis-C18:1 during the first $3 \mathrm{~h}$ of incubation. The initial production of cis-C18:1 observed during this period decreased linearly with the advance in maturity of timothy (Table 4). This effect is again probably related to the decreased concentration of $\mathrm{C} 18: 2$ and $\mathrm{C} 18: 3$ at the beginning of incubation with maturity of timothy. The concentration of cis-C18:1 started to decrease after $9 \mathrm{~h}$ of incubation, and the hydrogenation was almost completed at the end of incubation period (Figure 2, 1b).

In other study we also found that the concentrations of $\mathrm{C} 16: 0, \mathrm{C} 16: 1, \mathrm{C} 18: 0, \mathrm{C} 18: 2, \mathrm{C} 18: 3$, and TFA decreased linearly with growth stage. However, concentration of C14:0, C18:0 and C18:1 were not affected by the maturity of timothy. Gervais and St-Pierre (1979) also found a reduction in ether extraction with advance in maturity. They reported that the concentration of timothy ether extract was respectively 4.6, 3.3, 2.3, 2.0, 1.8 and $1.3 \%$ at vegetative stage, stem elongation, boot stage, heading stage, blooming and seed ripening stage.

\section{Effect of $\mathrm{N}$ fertilization}

Fertilized timothy had a higher non-hydrogenable fraction ( $\mathrm{x}$ ) of $\mathrm{C} 18: 2$ and $\mathrm{C} 18: 3$, as well as a higher hydrogenable fraction (y) of $\mathrm{C} 18: 3$ as compared to non fertilized timothy (Table 3). The amount of C18:0 formed during the biohydrogenation process was higher in fertilized than non-fertilized timothy (Table 3).

$\mathrm{N}$-fertilization had no effect $(\mathrm{P}>0.1)$ on the rate of disappearance of $\mathrm{C} 18: 2$ and $\mathrm{C} 18: 3$ as well as the rate of appearance of C18:0. However, $\mathrm{N}$ 
treatment increased the $\mathrm{ED}$ of $\mathrm{C} 18: 2$ and $\mathrm{C} 18: 3$, the EA of $\mathrm{C} 18: 0$, and the BP of $\mathrm{C} 18: 2, \mathrm{C} 18: 3$ and C18:0 (Table 3). The increased ED of C18:2 and $\mathrm{C} 18: 3$ in fertilized timothy was reflect of higher amount of $\mathrm{C} 18: 2$ and $\mathrm{C} 18: 3$ in fertilized timothy in the incubation mixture. In particular, $\mathrm{N}$-fertilization $\left(120 \mathrm{~kg} \mathrm{ha}{ }^{-1}\right)$ increased crude protein concentration (104.4 vs $\left.161.3 \mathrm{mg} \mathrm{g}^{-1} \mathrm{DM}\right)$ and decreased NDF concentration (62.7 vs 60.3 $\left.\mathrm{mg} \mathrm{g}^{-1} \mathrm{DM}\right)$ in timothy grass. Based on these results, we could assume that the metabolic component of forage biomass, which is made of cellular contents increased, whereas the structural component, which is made essentially of cell walls decreased with $\mathrm{N}$-fertilization. Belanger and McQueen (1998) also hypothesized that $\mathrm{N}$ deficiency increase the lignifications of grasses. The increase in the metabolic component, including chloroplasts, could cause a greater synthesis and accumulation of lipids and FA in the plant.

The average concentration of trans-C18:1 after 9, 24, and $36 \mathrm{~h}$, and the initial increase of cis-C18:1 at the beginning of the incubation was higher in fertilized timothy as compared with non fertilized timothy (Table 4). These results were probably related to the higher amount of $\mathrm{C} 18: 2$ and C18:3 in fertilized timothy at the beginning of the incubation.

Study the effect of nitrogen fertilization on the FA concentrations of timothy, we also found that nitrogen fertilization increased the concentration of C14:0, C16:0, C16:1, C18:1, C18:2, C18:3 and TFA. But the concentrations of $\mathrm{C} 12: 0$ and C18:0 were not affected by nitrogen fertilization.

In conclusion for this first trial, timothy grass should be harvested at an early growth stage, and fertilized adequately with $\mathrm{N}$ in order to maximize the amount of PUFA escaping ruminal biohydrogenation. Most of the effects observed were related to the initial concentration of $\mathrm{C} 18: 2$ and $\mathrm{C} 18: 3$ in timothy and no major difference has been noted on the rate of disappearance of PUFA during incubation period. In the current experiment, the apparent BP of C18:2 and C18:3 were calculated assuming a constant ruminal rate of passage $(\mathrm{k})$ of $0.06 \mathrm{~h}^{-1}$. However, Fredickson et al. (1993) reported that ruminal retention time increased, and passage rate of indigestible NDF decreased as the grazing season progressed in crossbred steers. If more mature forage, containing less PUFA, remains in the rumen for a longer period of time, this will exacerbate the effect of growth stage on the apparent ruminal BP of $\mathrm{C} 18: 3$ and $\mathrm{C} 18: 3$.

\section{Effect of conservation method}

The conservation treatment applied to timothy after the harvest had a significant effect $(\mathrm{P}<0.01)$ on the hydrogenable (y) and the non-hydrogenable (x) fraction of $\mathrm{C} 18: 2$ and $\mathrm{C} 18: 3$ (Table 5). Fresh grass had a higher non-hydrogenable fraction of $\mathrm{C} 18: 2$ and $\mathrm{C} 18: 3$ as compared to $\mathrm{GH}$, $\mathrm{H}$, and $\mathrm{S}$. The amount of $\mathrm{C} 18: 2$ and $\mathrm{C} 18: 3$ biohydrogenated were higher in $\mathrm{S}$ than in $\mathrm{H}$, GH, WG, and FG. The amount of C18:2 and C18:3 biohydrogenated were also higher in $\mathrm{H}$ and $\mathrm{S}$ than in GH. However, the amount of C18:0 produced during the biohydrogenation process was lower in $\mathrm{H}$ than in $\mathrm{S}, \mathrm{GH}$, and $\mathrm{FG}$. In $\mathrm{FG}$, the hydrogenable fraction of $\mathrm{C} 18: 3$ disappeared at a rate of $25,37,38$, and $43 \% \mathrm{~h}^{-1}$, respectively. Grass hay had the lowest rate of disappearance of C18:3 and a lower rate of disappearance of $\mathrm{C} 18: 2$ comparatively to $\mathrm{H}$ and S. These results show that $\mathrm{C} 18: 2$ and $\mathrm{C} 18: 3$ were more extensively hydrogenated by rumen fluid microorganisms when timothy was incubated as $\mathrm{H}$ and $\mathrm{S}$ instead of $\mathrm{GH}$ and/or WG.

The ED and BP of C18:2 and C18:3, as well as the EA and BP of C18:0 were significantly affected by timothy conservation treatment $(\mathrm{P}<0.01)$. Among all treatments, $\mathrm{S}$ had the highest $\mathrm{ED}$ of C18:2 and $\mathrm{C} 18: 3$ as well as highest EA of C18:0. On the other hand, GH had the lowest 
ammonia, and phosphorus (Graves and Vanderstappen, 1993).

Collins (1995) observed that in vitro DM digestibility was lower in $\mathrm{H}$ as compared with standing herbage (FG). Sniffen et al. (1992) also reported lower digestion rate constants for carbohydrate and protein fractions in $\mathrm{GH}$ as compared with S. A lower degradability of DM might have physically protected PUFA from ruminal hydrogenation; which may explain the lower rate of disappearance, and the increased BP of $\mathrm{C} 18: 3$ in GH as compared with FG or S.

The average concentration of trans-11 C18:1 in timothy after 9, 24, and $36 \mathrm{~h}$ of incubation was significantly affected $(\mathrm{P}<0.01)$ by the conservation treatment (Table 6). More trans-C18:1 was produced with $\mathrm{H}$ and $\mathrm{S}$ as compared with FG, WG, and GH. Lough and Anderson (1973) have found higher proportion of $\mathrm{C} 18: 1$ with trans unsaturation in the esterified fatty acids of silage than of fresh mixed grasses (ryegrass, timothy, and meadow fescue). According to these authors, the presence of trans-C18:1 in silage was a consequence of the isomerization and hy drogenation of PUFA occurring in silage. The analysis of FA composition of timothy conducted previously before the in vitro biohydrogenation experiment, had not revealed the existence of trans-C18:1 isomer in S. Therefore, the presence of trans18:1 in $\mathrm{S}$ measured after 9, 24, and $36 \mathrm{~h}$ of incubation was not produced during silage fermentation.

Trans-C18:1 is intermediates during ruminal biohydrogenation of PUFA. As reported previously, the amount of $\mathrm{C} 18: 2$ and $\mathrm{C} 18: 3$ biohydrogenated, and the rate of disappearance of these FA were higher in S as compared with GH. Such effect on the level of PUFA and the rate of biohydrogenation may explain the higher production of trans-C18:1 during the in vitro incubation of $\mathrm{S}$ and $\mathrm{H}$ as compared with GH. The initial production of cis-C18:1 during the first $9 \mathrm{~h}$ of incubation was higher in $\mathrm{S}$ and FG than in WG and $\mathrm{GH}$. This increase in the production of cis-18:1 at the beginning of the incubation period may also be a consequence of the higher levels of PUFA as well as the higher rate of biohydrogenation in $\mathrm{S}$ as compared with $\mathrm{GH}$. The concentration of cis-C18:1 after $36 \mathrm{~h}$ of incubation was higher in $\mathrm{S}$ than in WG and $\mathrm{GH}$. However, the level of cis-C18:1 remained higher at the end of the incubation period when compared with the first trial where the biohydrogenation of cis-C18:1 was almost complete (Table

Table 6. Concentrations of cis-C18:1 and trans-C18:1 in timothy at different conservation treatments after different incubation periods (Trial 2)

\begin{tabular}{|c|c|c|c|}
\hline \multirow{2}{*}{ Treatments } & \multicolumn{3}{|c|}{ Fatty acid $^{\mathrm{y})}\left(\mathrm{mg} \mathrm{g}^{-1} \mathrm{DM}\right)$} \\
\hline & trans-C18:1 & $c i s_{i}-\mathrm{C} 18: 1$ & $\mathrm{cis}_{f}-\mathrm{C} 18: 1$ \\
\hline Fresh grass $\left(230 \mathrm{~g} \mathrm{DM} \mathrm{kg}^{-1}\right)$ & $1.54^{\mathrm{d}}$ & $0.73^{\mathrm{ab}}$ & 0.66 \\
\hline Wilted grass (400 $\left.\mathrm{g} \mathrm{DM} \mathrm{kg}^{-1}\right)$ & $1.93^{\mathrm{c}}$ & $0.32^{\mathrm{d}}$ & 0.39 \\
\hline Grass hay $\left(850 \mathrm{~g} \mathrm{DM} \mathrm{kg}^{-1}\right)$ & $1.72^{\mathrm{cd}}$ & $0.41^{\mathrm{cd}}$ & 0.43 \\
\hline Haylage (400 $\mathrm{g} \mathrm{DM} \mathrm{kg}^{-1}$ ) & $2.75^{\mathrm{b}}$ & $0.54^{\mathrm{bc}}$ & 0.71 \\
\hline Silage $\left(230 \mathrm{~g} \mathrm{DM} \mathrm{kg}^{-1}\right)$ & $3.31^{\mathrm{a}}$ & $0.83^{\mathrm{a}}$ & 0.98 \\
\hline SEM & 0.07 & 0.06 & 0.13 \\
\hline Source of variation & \multicolumn{3}{|c|}{ Probability $^{\mathrm{x}}$} \\
\hline Treatments & $* *$ & $* *$ & \# \\
\hline
\end{tabular}


4). Kemp et al. (1975) reported that Fusocillus organisms, strictly anaerobic bacteria, isolated from the rumen of sheep were able to hydrogenate C18:3 to cis-15 C18:1 which appears not to be further hydrogenated either by pure cultures or by mixed rumen microorganisms. The inability of rumen bacteria to hydrogenated cis-15 C18:1 may explain the high level of cis-C18:1 observed in the incubation mixture after $36 \mathrm{~h}$ of incubation. It is not known however why such phenomenon was not observed in the first trial.

In other study, we also found that the conservation treatment applied to timothy after harvest (fresh grass, wilting, hay, haylage and silage) had a significant effect on the proportion of TFA, C18:3, C18:1, C16:1, C16:0 and C12:0. However, the concentration of C18:0 was not affected by conservation treatments. Fresh grass had higher concentration of TFA, C18:3, C18:2, $\mathrm{C} 18: 1, \mathrm{C} 18: 0, \mathrm{C} 16: 1, \mathrm{C} 16: 0$, and $\mathrm{C} 14: 0$ than wilted grass and grass hay. Haylage contained higher concentration of TFA, C18:3, C18:2, C16:0, and $\mathrm{C} 14: 0$ as compared to wilted grass and grass hay, and lower concentrations of TFA, C18:3, $\mathrm{C} 18: 2, \mathrm{C} 16: 1$, and $\mathrm{C} 16: 0$ than silage.

\section{Effect of haylage and silage additives}

Silage had higher hydrogenable fraction (y) of C18:2 and $\mathrm{C} 18: 3$ than $\mathrm{H}$. The ED of $\mathrm{C} 18: 3$, the BP of $\mathrm{C} 18: 2$, and the EA of C18:0 were higher in $\mathrm{S}$ than in $\mathrm{H}$ (Table 7). The initial production of cis-C18:1 at the beginning of the incubation period was also higher in $\mathrm{S}$ than in $\mathrm{H}$ (Table 8).

Table 7. Biohydrogenation of $\mathrm{C} 18: 2$ and $\mathrm{C} 18: 3$ and appearance of $\mathrm{C} 18: 0$ during in vitro incubation of timothy silage and haylage with and without additives (Trial 3)

\begin{tabular}{|c|c|c|c|c|c|c|c|c|c|c|c|c|c|c|}
\hline \multirow{3}{*}{\multicolumn{2}{|c|}{$\begin{array}{l}\text { Fatty acid } \\
\text { Parameter }\end{array}$}} & \multirow{2}{*}{\multicolumn{6}{|c|}{ Treatment $^{2)}$}} & \multirow{3}{*}{ SEM } & \multicolumn{6}{|c|}{ Probability ${ }^{3)}$} \\
\hline & & & & & & & & & \multirow{2}{*}{$\begin{array}{c}\text { Treatment } \\
\text { effect }\end{array}$} & \multicolumn{5}{|c|}{ Constrasts } \\
\hline & & $\mathrm{H}$ & $\mathrm{Hi}$ & Hfa & $\mathrm{S}$ & $\mathrm{Si}$ & Sfa & & & Hvs Hi & Hvs Hfa & Hvs S & $\mathrm{S}$ vs $\mathrm{Si}$ & S vs Sfa \\
\hline \multirow[t]{5}{*}{$\mathrm{C} 18: 2$} & $\mathrm{x}$ & 0.90 & 0.92 & 1.03 & 1.10 & 0.90 & 1.15 & 0.08 & NS & NS & NS & NS & NS & NS \\
\hline & $\mathrm{y}$ & 3.01 & 2.76 & 2.52 & 3.74 & 3.50 & 2.99 & 0.23 & \# & NS & NS & \# & NS & \# \\
\hline & $\mathrm{Z}$ & 0.25 & 0.25 & 0.27 & 0.25 & 0.20 & 0.30 & 0.03 & NS & NS & NS & NS & NS & NS \\
\hline & ED & 2.41 & 2.19 & 2.05 & 3.01 & 2.69 & 2.47 & 0.20 & NS & NS & NS & NS & NS & NS \\
\hline & $\mathrm{BP}$ & 1.50 & 1.50 & 1.50 & 1.83 & 1.71 & 1.67 & 0.06 & $*$ & NS & NS & $* *$ & NS & NS \\
\hline \multirow[t]{5}{*}{$\mathrm{C} 18: 3$} & $\mathrm{x}$ & 0.75 & 0.60 & 0.84 & 0.55 & 0.60 & 0.66 & 0.06 & \# & NS & NS & \# & NS & NS \\
\hline & $\mathrm{y}$ & 6.01 & 5.75 & 5.48 & 7.25 & 7.00 & 7.26 & 0.32 & $*$ & NS & NS & $*$ & NS & NS \\
\hline & $\mathrm{z}$ & 0.43 & 0.36 & 0.53 & 0.40 & 0.40 & 0.55 & 0.13 & $* *$ & NS & $*$ & NS & NS & $* *$ \\
\hline & ED & 5.26 & 4.91 & 4.91 & 6.30 & 6.09 & 6.54 & 0.27 & $* *$ & NS & NS & $*$ & NS & NS \\
\hline & $\mathrm{BP}$ & 1.50 & 1.44 & 1.40 & 1.50 & 1.51 & 1.37 & 0.06 & NS & NS & NS & NS & NS & NS \\
\hline \multirow[t]{5}{*}{ C18:0 } & $\mathrm{a}$ & 0.95 & 0.50 & 0.07 & 0.36 & 0.19 & 0.72 & 0.28 & NS & NS & \# & $*$ & NS & \# \\
\hline & $\mathrm{b}$ & 8.58 & 7.76 & 9.87 & 11.24 & 9.73 & 11.63 & 0.78 & \# & NS & NS & $\#$ & NS & NS \\
\hline & $\mathrm{c}$ & 0.11 & 0.24 & 0.14 & 0.15 & 0.26 & 0.10 & 0.04 & NS & \# & NS & NS & NS & NS \\
\hline & EA & 6.52 & 6.57 & 6.88 & 7.71 & 7.47 & 7.55 & 0.32 & NS & NS & NS & \# & NS & NS \\
\hline & BP & 7.47 & 7.07 & 6.95 & 7.35 & 7.66 & 8.27 & 0.43 & NS & NS & NS & NS & NS & NS \\
\hline
\end{tabular}


These results confirm the observations made in the previous trial, and may be explained by the higher concentrations of $\mathrm{C} 18: 2$ and $\mathrm{C} 18: 3$ in $\mathrm{S}$ than in $\mathrm{H}$.

The addition of $6 \mathrm{~L}$ of formic acid $\mathrm{t}^{-1} \mathrm{FM}$ increased the rate of biohydrogenation of $\mathrm{C} 18: 3$ by $23 \%$ in $\mathrm{H}$ and by $38 \%$ in $\mathrm{S}$, but it decreased the hydrogenable fraction (y) of C18:2 from 3.74 to $2.99 \mathrm{mg} \mathrm{g}^{-1} \mathrm{DM}$ in $\mathrm{S}$ (Table 7). We previously observed a lower C18:2 concentration in Sfa than in $\mathrm{S}$, which may explain this decrease of the hydrogenable fraction of C18:2 in Sfa. The LAB inoculant added to $\mathrm{H}$ and $\mathrm{S}$ had no significant effect on all parameters of kinetic disappearance of $\mathrm{C} 18: 2$ and $\mathrm{C} 18: 3$, and appearance of C18:0 during the in vitro incubation, except for the rate of appearance of C18:0 which was higher in $\mathrm{Hi}$ than $\mathrm{H}$.

The addition of formic acid and LAB inoculant in $\mathrm{H}$ and $\mathrm{S}$ had no effect on the average concentration of trans-C18:1 after 9, 24, and 36 $\mathrm{h}$ of incubation. However, the initial production of cis-C18:1 at the beginning of the incubation period was increased with the addition of LAB inoculant and formic acid in timothy $\mathrm{H}$, but was decreased by the same additives in timothy $\mathrm{S}$ (Table 8). The addition of LAB inoculant in silage allows this microbial population to dominate fermentation and reduce the time until rapid lactic acid production begins (Jasted, 1995). The addition of formic acid in ensiled forage decreases silage $\mathrm{pH}$, which reduces the extent of fermentation. Dewhurst and King (1998) reported that the use of formic acid as additive in wilted and non-wilted perennial ryegrass silage decreased silage fermentation, and consequently the levels of acetic, lactic and butyric acids produced. These results suggest that formic acid have an inhibiting effect on the activity of cellulolytic and proteolytic microorganisms responsible of carbohydrates and protein fermentation in silage. The levels of volatile FA produced during silage

Table 8. Concentrations of cis-C18:1 and trans-C18:1 in timothy silage and haylage at different incubation periods with or without additives (Trial 2)

\begin{tabular}{|c|c|c|c|}
\hline \multirow{2}{*}{ Treatments } & \multicolumn{3}{|c|}{ Fatty acid $^{\mathrm{x})}\left(\mathrm{mg} \mathrm{g}^{-1} \mathrm{DM}\right)$} \\
\hline & trans-C18:1 & $c i s_{i}-\mathrm{C} 18: 1$ & $\operatorname{cis}_{f}-\mathrm{C} 18: 1$ \\
\hline Haylage $\left(400 \mathrm{~g} \mathrm{DM} \mathrm{kg}^{-1}\right)(\mathrm{H})$ & 3.12 & 0.38 & 0.44 \\
\hline Haylage with $\mathrm{LAB}$ inoculum $\left(10^{6} \mathrm{CFU} \mathrm{g}{ }^{-1} \mathrm{DM}\right)(\mathrm{Hi})$ & 3.05 & 0.67 & 0.46 \\
\hline Haylage with formic acid $\left(6 \mathrm{Lt}^{-1} \mathrm{FM}\right)(\mathrm{Hfa})$ & 3.18 & 0.64 & 0.55 \\
\hline Silage $\left(230 \mathrm{~g} \mathrm{DM} \mathrm{kg}^{-1}\right)(\mathrm{S})$ & 3.92 & 1.07 & 1.09 \\
\hline Silage with LAB inoculum $\left(10^{6} \mathrm{CFU} \mathrm{g}^{-1} \mathrm{DM}\right)(\mathrm{Si})$ & 3.88 & 0.80 & 0.60 \\
\hline Silage with formic acid $\left(6 \mathrm{Lt}^{-1} \mathrm{FM}\right)(\mathrm{Sfa})$ & 3.65 & 0.61 & 0.52 \\
\hline SEM & 0.12 & 0.07 & 0.14 \\
\hline Source of variation & \multicolumn{3}{|c|}{ Probability $^{\text {z) }}$} \\
\hline Treatments & $* *$ & $* *$ & NS \\
\hline $\mathrm{H}$ vs $\mathrm{Hi}$ & NS & * & NS \\
\hline H vs Hfa & NS & \# & NS \\
\hline $\mathrm{H}$ vs $\mathrm{S}$ & $* *$ & $* *$ & $*$ \\
\hline $\mathrm{S}$ vs $\mathrm{Si}$ & NS & $\#$ & \# \\
\hline S vs Sfa & NS & $* *$ & $*$ \\
\hline
\end{tabular}

x) trans-C18:1 = average concentration of trans-C18:1 at 9, 24, 36 h of incubation.

cis $_{i}-\mathrm{C} 18: 1=$ initial production of cis-C18:1 during the first $9 \mathrm{~h}$ of incubation, and.

$c i s_{f}-\mathrm{C} 18: 1=$ final concentration of $c i s-\mathrm{C} 18: 1$ after $36 \mathrm{~h}$ of incubation.

z) NS, \#, *,** =non significant, and significant at $\mathrm{P}<0.1, \mathrm{P}<0.05$, and $\mathrm{P}<0.01$, respectively. 
fermentation were not determined in the current experiment. Nevertheless, the addition of formic acid in $\mathrm{S}$ and $\mathrm{H}$ increased the rate of biohydrogenation of $\mathrm{C} 18: 3$. However, this increase in the rate of biohydrogenation had no major effect on the apparent BP of C18:3.

When study the effect of haylage and silage additives, our results showed that the dose of LAB inoculant $\left(10^{5}\right.$ vs. $\left.10^{6} \mathrm{CFU} \mathrm{g}^{-1} \mathrm{FM}\right)$ had no significant effect on all fatty acid concentrations in hay and silage except for C18:2 which tended to be lower with the highest dose of inoculant. However, the dose of formic acid $(2 \mathrm{~L}$ vs. $\left.6 \mathrm{~L} \mathrm{t}^{-1} \mathrm{FM}\right)$ had no significant effect on the concentration of all fatty acids in hay and silage $(\mathrm{P}>0.1)$.

\section{CONCLUSIONS}

This series of experiments indicate that the BP of $\mathrm{C} 18: 2$ and $\mathrm{C} 18: 3$ in timothy decreased with maturity, and increased with $\mathrm{N}$-fertilization. Most of the effects observed were related to the initial concentration of $\mathrm{C} 18: 2$ and $\mathrm{C} 18: 3$ in timothy, and no major difference has been noted on the rate of disappearance of PUFA during incubation period. The concentration of $\mathrm{C} 18: 3$ was higher in timothy $\mathrm{S}$ and $\mathrm{H}$ as compared with $\mathrm{GH}$ at the beginning of the incubation period. However, the rate of biohydrogenation of $\mathrm{C} 18: 3$ was higher in $\mathrm{S}$ and $\mathrm{H}$ as compared with $\mathrm{GH}$. As a consequence, the $\mathrm{BP}$ of $\mathrm{C} 18: 3$ was higher when timothy was harvested as $\mathrm{GH}$. Moreover, the rates of $\mathrm{C} 18: 2$ and $\mathrm{C} 18: 3$ biohydrogenation and the amount of $\mathrm{C} 18: 2$ and C18:3 escaping ruminal biohydrogenation were not affect by the addition of formic acid or LAB inoculant in $\mathrm{H}$ and $\mathrm{S}$. It is therefore recommended to harvest timothy at an early growth stage, fertilize it with $\mathrm{N}$, and conserve it as grass hay in order to maximize the amount of $\mathrm{C} 18: 3$ that $\mathrm{BP}$ the ruminal biohydrogenation.

\section{ABSTRACT}

In vitro anaerobic incubations of timothy (Phleum pretense L.) forage with bovine rumen fluid were conducted at $39^{\circ} \mathrm{C}$ for $0,3,6,9,24$, and $36 \mathrm{~h}$ in three trials to examine the biohydrogenation of linolenic (C18:3) and linoleic acids (C18:2) and their bypass from the rumen. The objectives of the first trial was to study the effect of growth stage (stem elongation, early heading, late heading, and early flowering) and $\mathrm{N}$-fertilization ( 0 and $120 \mathrm{~kg} \mathrm{~N} \mathrm{ha}{ }^{-1}$ ) on in vitro biohydrogenation of $\mathrm{C} 18: 2$ and $\mathrm{C} 18: 3$. The hydrogenable fraction, the effective disappearance and the bypass of $\mathrm{C} 18: 2$ and $\mathrm{C} 18: 3$ were high in timothy harvested at stem elongation, and decrease linearly with maturity. The $\mathrm{N}$-fertilization increased the hydrogenable fraction of $\mathrm{C} 18: 3$, the effective disappearance and the bypass of $\mathrm{C} 18: 2$ and C18:3. However, the rate of disappearance of C18:2 and C18:3 were not affected by maturity and $\mathrm{N}$-fertilization $(\mathrm{P}>0.1)$. In trial 2, the effect of timothy conservation method on in vitro $\mathrm{C} 18: 2$ and $\mathrm{C} 18: 3$ biohydrogenation was determined. Silage had the highest effective disappearance of C18:2 and $\mathrm{C} 18: 3$, and grass hay had lowest one. The amounts of $\mathrm{C} 18: 2$ and $\mathrm{C} 18: 3$ biohydrogenated were higher in haylage and silage than in grass hay. Comparative to haylage timothy, the bypass of C18:3 was higher in fresh grass, wilted grass and grass hay. The bypass of C18:2 was higher in fresh grass and silage in comparison to grass hay and haylage. In trial 3, the effects of formic acid and Lactobacillus plantarum inoculum addition to timothy haylage and silage on C18:2 and C18:3 disappearance and bypass were studied. Haylage and silage additives had no effect $(\mathrm{P}>0.1)$ on effective disappearance and bypass of $\mathrm{C} 18: 2$ and C18:3. The addition of formic acid increased the rate of biohydrogenation of $\mathrm{C} 18: 3$ in haylage and silage, but it decreased the hydrogenable fraction of $\mathrm{C} 18: 2$ in silage. The 
results of these three incubation trials show that the hydrogenable fraction and the bypass of $\mathrm{C} 18: 2$ and $\mathrm{C} 18: 3$ in timothy decreased with maturity and increased with $\mathrm{N}$-fertilization. Higher amount of C18:2 and C18:3 were biohydrogenated in haylage and silage than in grass hay, and C18:3 ruminal disappearance was higher in fresh grass, wilted grass and grass hay than in haylage.

\section{REFERENCES}

1. Ashes, J. R., Gulati, S. K. and Scott, T. W. 1997. Potential to alter the content and composition of milk fat through nutrition. J. Dairy Sci. 80: 2204 -2212 .

2. Belanger, G. and McQueen, R. E. 1998. Analysis of the nutritive value of timothy grown with varies N nutrition. Grass Forage Sci. 53:109-119.

3. Belanger, G., Michaud, R., Jefferson, P. G., Tremblay, G. F. and Bregard, A. 2001. Improving the nutritive value of timothy through management and breeding. Can. J. Plant Sci. 81:577-585.

4. Bauchart, D., Verite, R. and Remond, B. 1984. Long-chain fatty acid digestion in lactating cows fed fresh grass from spring to autumn. Can. J. Anim. Sci. 64(suppl):330-331.

5. Bauchart, D., Doreau, M. and Legay-Carmier, F. 1985. Utilisation digestive des lipids et consequences de leur introduction sur la digestion du ruminant. Bull. Tech. C. R. Z. V. 61:65-77.

6. Collins, M. 1995. Hay preservation effects yield and quality. In Post-harvest physiology and preservation of forages, K. J. Moore and M. A. Peterson(Ed.). Special Publication No. 22. Crop Science Society of America, Inc., Madison, WI. pp. 67-89.

7. Demeyer, D. and Doreau, M. 1999. Targets and procedures for altering ruminant meat and milk lipids. Proc. Nutr. Soc. 58:593-607.

8. Dewhurst, R. J. and King, P. J. 1998. Effects of extended wilting, shading and chemical additives on the fatty acids in laboratory grass silage. Grass
Forrage Sci. 53: 219-224.

9. Dhiman, T. R., Anand, G. R., Satter, L. D. and Pariza, M. 1999. Conjugated linoleic acid content of milk from cows fed different diets. J. Dairy Sci. 82:2146-2156.

10. Fredrickson, E. L., Galyean, M. L., Branine, M. E., Sowell, B. and Wallace, J. D. 1993. Influence of ruminally dispensed monensin and forage maturity on intake and digestion. J. Range Manage. 46: 214-220.

11. Fujimoto, K., Kimoto, H., Shishikura, M., Endo, Y. and Ogimoto, K. 1993. Biohydrogenation of linoleic acid by anaerobic bacteria isolated from rumen. Biosci. Biotech. Biochem. 57:1026-1027.

12. Gerson, T. A., John, A. and King, A. S. D. 1985. The effects of dietary starch and fiber on the in vitro rates of lipolysis and hydrogenation by sheep rumen digesta. J. Agric. Sci. (Camb) 105: 27-30.

13. Gerson, T. A. and Sinclair, B. R. 1983. The effect of dietary $\mathrm{N}$ on in vitro lipolysis and fatty acid hydrogenation in rumen digesta from sheep fed diets high in starch. J. Agric. Sci. (Camb) 101:97-101.

14. Gervais, P. and St-Pierre, J. C. 1979. Influence $\mathrm{du}$ stade de croissance a' la premiere recolte sur le rendement, la composition chimique et les reserves nutritives de la fleole des pres. Can. J. Plan Sci. 59:177-183.

15. Graves, R. E. and Vanderstappen, P. J. 1993. Environmental problems with silage effluent. Silage Production: From seed to animal. Syracuse, NY: Northeast Regional Agricultural Engineering Service. NRAES-5.

16. Gulati, S. K., Scott, T. W. and Ashes, J. R. 1997. In vitro assessment of fat supplements for ruminant. Anim. Feed Sci. Tech. 64:127-132.

17. Harfoot, C. G. 1981. Lipid metabolism in the rumen. In Lipid metabolism in ruminant animals, W.W. Christie(Ed.). Pergamon Press, Oxford. UK. pp. 21-25.

18. Harfoot, C. G. and Hazlewood, G. P. 1988. Lipid 
metabolism in the rumen. In The rumen microbial ecosystem, P.N. Hobson (Ed). Elsevier Applied Science, New York, NY. pp. 285-22.

19. Harfoot, C. G., Noble, R. C. and Moore, J. H. 1973. Factors influencing the extent of biohydrogenation of linoleic acid by rumen micro-organism in vitro. J. Sci. Food. Agric. 24:961-970.

20. Hawke, J. C. 1973. Lipids. Page 213-263 in G.W. Butler and R.W. Bailey, eds. Chemistry and biochemistry of herbage. Vol. 1, Acadenic Press, New York, NY.

21. Jaster, E. H. 1995. Legume and grass silage preservation. In Post-harvest physiology and preservation of forages, K. J. Moore and M. A. Peterson(Ed.). Special Publication No. 22. Crop Science Society of America, Inc., Madison, WI. pp. 91-115.

22. Kellens, M. J., Goderis, H. L. and Tobback, P. P. 1986. Biohydrogenatio $\mathrm{n}$ of unsaturated fatty acids by a mixed culture of rumen microorganismss. Biotechnol. Bioeng. 28:1268-1276.

23. Kemp, P. and Lander, D. J. 1983. The hydrogenation of $\gamma$ linoleic acid by pure cultures of two rumen bacteria. Biochem. J. 216:519-522.

24. Kemp, P. and Lander, D. J. 1984. The hydrogenation of some cis-and trans-octadecenoic acids to stearic acid by a rumen Fusocillus sp. Br. J. Nutr. 52: 165-170.

25. Kepler, C. R. and Tove, S. B. 1976. Biohydrogenation of unsaturated fatty acids. J. Biol. Chem. 242:5686-5692.

26. Kepler, C. R., Tucker, W. P. and Tove, S. B. 1970. Biohydrogenation of unsaturated fatty acids. Substrate specificity and inhibition of linoleate $\Delta^{12}$-cis, $\Delta^{11}$ trans isomerase from Butyrivibrio fibrisolvens. J. Biol. Chem. 245:3612-3620.

27. Lough, A. K. and Anderson, L. J. 1973. Effect of ensilage on the lipids of pasture grasses. Proc. Nutr. Soc. 32:61-A.
28. McDonald, P., Edwards, R.a. and Greenhalgh, J.F.D. 1988. Lipids. Pages $26-41$ in Animal nutrition, $4^{\text {th }}$ ed, Longman Scientific and Technical. New York, NY.

29. MacDonald, P., Henderson, A. R. and Heron, S. J. E. 1991. Losses during ensilage. In The biochemistry of silage, P. McDonald, N. Henderson and S. Heron (Ed.), Chalcombe publications. Aberystwyth, UK. pp. 237-249.

30. Mayne, C. S. and Gordon, F. J. 1986. Effect of harvesting system on nutrient losses during silage making. 2. In silo-losses. Grass Forage Sci. 41: 341-351.

31. Orskov, E. R. and McDonald, I. 1979. The estimation of protein degradability in the rumen from incubation measurements weighted according to rate of passage. J. Agric. Sci. (Camb) 92: 499-503.

32. SAS Institute, Inc. 1985. SAS/STAT ${ }^{\circledR} \quad$ User's Guide. Version 6.0. SAS Institute, Inc., Cary, NC. 33. Sniffen, C. L., O'Connor, J. D., Van Soest, P. J., Fox, D. G. and Russell, J. B. 1992. A net carbohydrate and protein system for evaluating cattle diets: II. Carbohydrate and protein availability. J. Anim. Sci. 70:3562-3577.

34. Van Nevel, C. J. and Demeyer, D. I. 1996. Effect of $\mathrm{pH}$ on biohydrogenation of polyunsaturated fatty acids and their $\mathrm{Ca}$-salts by rumen microorganismss in vitro. Arch. Anim. Nutr. 49:151-157.

35. Weenink, R. O. 1961. Acetone-soluble lipids of grasses and other forage plants. I. Galactolipids of red clover (Trifolium pretense) leaves. J. Sci. Food Agric. 12:34-38.

36. Weenink, R. O. 1964. Lipids of the acetone insoluble fraction from red-clover (Trifolium pretense) leaves. Biochem. J. 93:606-611.

37. Williams, C. M. 2000. Dietary fatty acids and human health. Ann. Zootech. 49:165-180.

(접수일자 : 2005. 9. 22. / 채택일자 : 2005. 12. 13.) 